\title{
Development of a Sensitive Colorimetric-PCR Assay for Detection of Viruses in Woody Plants
}

\author{
Adib Rowhani, Plant Pathology Specialist, Lenka Biardi, Postgraduate Researcher, Geoffrey Routh, Postdoctoral \\ Fellow, Steve D. Daubert, Staff Research Associate, and Deborah A. Golino, Extension Specialist, Department of \\ Plant Pathology, University of California, Davis 95616
}

\begin{abstract}
Rowhani, A., Biardi, L., Routh, G., Daubert, S. D., and Golino, D. A. 1998. Development of a sensitive colorimetric-PCR assay for detection of viruses in woody plants. Plant Dis. 82:880884.

Diagnostic methods employing the polymerase chain reaction (PCR) provide the most sensitive means currently available for detecting viruses in woody plants. A new technique has been tested that does not rely on gel electrophoresis or molecular hybridization to detect virus-specific PCR products. This colorimetric method for detection of PCR products from woody plants was demonstrated to be at least as sensitive as gel analysis. When combined with immunocapture of virions from plant sap, colorimetric detection provides a means to apply PCR technology to a large number of samples. Here, we report on the use of this technique for detection and quantitation of a walnut isolate of cherry leafroll virus (CLRV-W), citrus tristeza virus (CTV), prune dwarf virus (PDV), prunus necrotic ringspot virus (PNRSV), and tomato ringspot virus (ToRSV) in woody and herbaceous plants. For purified virus preparations, detection limits ranged from $100 \mathrm{pg} / \mathrm{ml}$ to $100 \mathrm{ag} / \mathrm{ml}$. We also describe the colorimetric PCR detection of CTV in pooled samples.
\end{abstract}

Control of viral diseases in woody crops is best accomplished by establishing new plantings from virus-tested plants. Programs for the certification of nursery stock require fast, sensitive, inexpensive screening methods for detection of these pathogens. Screening for some diseases can be accomplished by inoculating indicator plants in the field or in the greenhouse. This procedure is not ideal, however, since it requires considerable time for symptom development, is labor intensive, and requires significant amounts of greenhouse or field space. In addition, the reliability of such indexing programs can suffer from technical difficulties commonly encountered when transmitting viruses from woody plants to new hosts. A second approach to screening plants for disease is to develop assays to quickly detect the causal agent or agents. The enzyme-linked immunosorbent assay (ELISA) is a rapid, cost-effective means for detecting viruses in woody plants. However, ELISA has its own limitations, lacking the sensitivity to reliably detect viruses when they occur at low titers $(3,7,14,23)$. Additionally, the highly purified virus preparations required to initially produce, and then to restock, the

Corresponding Author: Adib Rowhani

E-mail: akrowhani@ucdavis.edu

Accepted for publication 17 April 1998.

Publication no. D-1998-0605-01R

(C) 1998 The American Phytopathological Society antisera needed for this test are difficult, sometimes impossible, to obtain. This is especially true in cases where singly infected plants cannot be obtained.

Reverse transcription-polymerase chain reaction (RT-PCR) has the potential to be an extremely sensitive alternative to ELISA, providing a means for detecting viruses in woody plants throughout the year $(12,20)$, even during seasons of low titer. The design of nucleic acid primers for RT-PCR is a demanding task, and primer sequences may require revision in the advent of evolved strains of a particular virus. Nonetheless, PCR primers are more easily produced than antiserum for ELISA. As a detection technique, RT-PCR requires extensive manipulation of each sample prior to the RT-PCR reactions and electrophoretic or blot hybridization analysis of each RT-PCR product afterward $(14,20)$. Immunocapture and direct binding techniques were developed to reduce the complexity of sample preparation for RT-PCR $(8,11,17,18,26)$. Now it is no more complex or labor intensive to prepare woody plant samples for RT-PCR than it is to prepare them for ELISA (21). Immunocapture techniques still require production of antibodies, but the quality and specificity needed is not as high as that required for ELISA. Immunocapture and direct binding PCR were also shown to be 100 to 10,000 times more sensitive than ELISA (21).

When RT-PCR data require electrophoretic or blot hybridization analysis for interpretation, the technology is still too cumbersome for large-scale sampling efforts. Here, we analyze a method for a much simplified, colorimetric assay for virus-specific RT-PCR products that eliminates the need for electrophoretic analyses. Colorimetric PCR is demonstrated to be a rapid and sensitive method for detection of cherry leafroll virus-walnut isolate (CLRV$\mathrm{W}$ ), citrus tristeza virus (CTV), prune dwarf virus (PDV), prunus necrotic ringspot virus (PNRSV), and tomato ringspot virus (ToRSV). This technique makes it feasible to design large-scale sampling efforts around the extremely sensitive RTPCR virus detection methods.

\section{MATERIALS AND METHODS}

Virus isolates and host plants. Viruses and hosts used included CLRV-W8 (16) in cucumber (Cucumis sativus L.) and walnut (Juglans regia L.), five strains (ranging from mild to severe) of CTV in orange (Citrus sinensis (L.) Osbeck), a PDV isolate in cucumber and cherry (Prunus avium L. cv. Bing), PNRSV isolate Fulton G (5) in cucumber and a rugose strain in cherry, and ToRSV-PYBM (10) in cucumber and cherry. The CTV isolates were kindly provided by M. Polek, and the PDV, PNRSV, and ToRSV isolates in cherry were kindly provided by J. K. Uyemoto.

Virus purification and sample preparation. The following procedures were used to purify viruses for this work. CLRVW was purified from Chenopodium quinoa Willd. as described by Rowhani et al. (22). CTV was partially purified according to the method of Bar-Joseph et al. (2). PDV and PNRSV were prepared as previously described $(4,6)$. ToRSV was prepared according to Hoy and Mircetich (10). Concentrations of the CLRV-W, PDV, PNRSV, and ToRSV preparations were determined by absorbance measurement at $260 \mathrm{~nm}$. For determination of detection limits, viruses were serially diluted in dilution buffer $(1: 10 \mathrm{wt} / \mathrm{vol}$, Dilution buffer $=500$ $\mathrm{mM}$ Tris-Cl, $\mathrm{pH} 7.4,2 \%$ PVP-40, $1 \%$ PEG $8000,140 \mathrm{mM} \mathrm{NaCl}, 0.05 \%$ Tween 20 [17]). For analyses of pooled samples for CTV, sap extracts taken from infected sweet orange trees were diluted with sap extracted from healthy trees. Plant sap extracts for IC-PCR virus detection were prepared from young leaves of the woody plants and symptomatic leaves of cucumber. Plant tissue was extracted in dilution buffer in mesh sample extraction bags 
(Agdia, Inc., Elkhart, IN) using a Homex 6 homogenizer (Bioreba Ag. Inc., South Bend, IN).

IC-PCR. Immunocapture PCR was performed on the plant sap extracts. Sterile 0.5-ml polypropylene microcentrifuge tubes (Outpatient Services Inc., Petaluma, CA) or 96-well microtiter plates (NuncImmuno Plate, Fisher Scientific Co., Santa Clara, CA) were precoated for $1 \mathrm{~h}$ at $37^{\circ} \mathrm{C}$ with $50 \mu \mathrm{l}$ of antiviral $\mathrm{IgG}$ (i.e., $4 \mu \mathrm{g} / \mathrm{ml}$ in $50 \mathrm{mM}$ sodium carbonate buffer, $\mathrm{pH}$ 9.6, before use). The precoated tubes or plates were rinsed three times with ELISA washing buffer (PBS containing 0.05\% Tween 20). The tubes or plates were then incubated for $1.5 \mathrm{~h}$ at $37^{\circ} \mathrm{C}$ with $50 \mu \mathrm{l}$ of plant extract and washed three times in ELISA washing buffer. Synthesis of cDNA was performed in the tubes or plates according to the methods of Saiki et al. (24) and Lion and Haas (13). Specifically, $25 \mu \mathrm{l}$ of reverse transcriptase solution $(2.5 \mu \mathrm{l}$ of $10 \times$ PCR buffer $[500 \mathrm{mM} \mathrm{KCl}, 100 \mathrm{mM}$ Tris-Cl, pH 9.0], $5 \mu \mathrm{l}$ of $2 \mathrm{mM}$ dNTP mixture [Pharmacia Biotech, Piscataway, $\mathrm{NJ}$ ] containing $0.1 \mathrm{mM}$ digoxygenin-11UTP [Boehringer-Mannheim Biochemicals, Indianapolis, IN], $4.5 \mu \mathrm{l}$ of $25 \mathrm{mM}$ $\mathrm{MgCl}_{2}, \quad 0.4 \mu \mathrm{l}$ of RNasin $[40 \mathrm{U} / \mu \mathrm{l}$, Promega Corp., Madison, WI]), 200 ng of complementary (C) primer (Table 1), 10.5 $\mu \mathrm{l}$ of sterile distilled water, $0.25 \mu \mathrm{l}$ of Molony Murine Leukemia virus (M-MLV)reverse transcriptase $(200 \mathrm{U} / \mu \mathrm{l}$, Promega) and incubated at $42^{\circ} \mathrm{C}$ for $15 \mathrm{~min}$ (tubes) or $30 \mathrm{~min}$ (plates). At this point, solutions containing reverse transcriptase reactions performed in microtiter plates were transferred to $0.5-\mathrm{ml}$ microcentrifuge tubes. Following reverse transcription, the soluwere added to the immunocaptured virions tions (from either method) were overlaid

with mineral oil, placed in a thermocycler (Model 480, Perkin Elmer-Cetus, Foster City, CA) heated to $99^{\circ} \mathrm{C}$ for $5 \mathrm{~min}$, and then chilled to $5^{\circ} \mathrm{C}$ for $5 \mathrm{~min}$. PCRs were carried out by adding $75 \mu$ lof amplification solution $(7.5 \mu \mathrm{l}$ of $10 \times$ PCR buffer, $3.75 \mu \mathrm{l}$ of $25 \mathrm{mM} \mathrm{MgCl} 2,200 \mathrm{ng}$ of homologous $(\mathrm{H})$ primer (Table 1), $63.1 \mu \mathrm{l}$ of sterile distilled water, and $0.5 \mu$ l of Taq DNA polymerase (5 U/ $\mu$, Promega) to each tube. The tubes were then incubated for $2 \mathrm{~min}$ at $95^{\circ} \mathrm{C}$, then subjected to 35 cycles of $1 \mathrm{~min}$ at $95^{\circ} \mathrm{C}, 1 \mathrm{~min}$ at $53^{\circ} \mathrm{C}$, and $1 \mathrm{~min}$ at $72^{\circ} \mathrm{C}$. A final incubation at $72^{\circ} \mathrm{C}$ was carried out for $7 \mathrm{~min}$. The samples were then chilled to $4^{\circ} \mathrm{C}$ until removal from the thermocycler.

RT-PCR. RT-PCR was also carried out on purified virions using the methods described above, but with two modifications. First, $2 \mu \mathrm{l}$ of purified virus was added directly to the reverse transcription reaction to a final volume of $20 \mu \mathrm{l}$, and second, the components of the amplification cocktail were adjusted so that the final volume was $80 \mu \mathrm{l}$ per tube. The oligonucleotide primers used for PCR amplification and the virusspecific 5'-biotin-labeled oligonucleotide detection probes used in these assays were prepared by Oligos Etc. (Wilsonville, OR), and their sequences are shown in Table 1.

Electrophoretic analysis of PCR products. Aliquots (15 $\mu \mathrm{l}$ each) of the PCR reactions were resolved electrophoretically on a $1.5 \%$ agarose gel using $1 \times$ TBE buffer (25) or $8.5 \%$ acrylamide gel (1:37 bisacrylamide:acrylamide) using $1 \times$ TAE (25). Electrophoresis was carried out at $10 \mathrm{~V} / \mathrm{cm}$ for $1 \mathrm{~h}$ and $6 \mathrm{~V} / \mathrm{cm}$ for $6 \mathrm{~h}$ for agarose and acrylamide, respectively. The gels were stained for $15 \mathrm{~min}$ in a $200 \mathrm{ng} / \mathrm{ml}$ ethidium bromide solution. PCR products were then visualized on a UV transillumi-

Table 1. Oligonucleotides used for colorimetric reverse transcription-polymerase chain reaction (RTPCR) detection of five viruses of woody plants

\begin{tabular}{|c|c|c|c|c|}
\hline Virus $^{\mathrm{a}}$ & Oligonucleotide sequence $^{b}$ & Function ${ }^{\mathrm{c}}$ & $\begin{array}{l}\text { Product } \\
\text { size }(k b)^{d}\end{array}$ & Ref. \\
\hline \multirow[t]{3}{*}{$\overline{\text { CLRV }}$} & $5^{\prime}$ GGC AGC GAG CTT CGA GCC GCG TAA GG 3' & $\mathrm{H}$ & 0.39 & EMBL \\
\hline & 5' GCT GTC TTT CCA GCA GTC AAA CTA AT 3' & $\mathrm{C}$ & & Access. \\
\hline & $5^{\prime}$ CGT GTC GTT GCC GTA AGC AA $3^{\prime}$ & B & & Z34265 \\
\hline \multirow{3}{*}{ CTV } & $5^{\prime}$ AAC GCC CTT CGA GTC TGG GGT AGG A 3' & $\mathrm{H}$ & 0.27 & (15) \\
\hline & $5^{\prime}$ TCA ACG TGT GTT GAA TTT CCC AAG C $3^{\prime}$ & $\mathrm{C}$ & & \\
\hline & $5^{\prime}$ GCG GGA CGT CCG CTA GAT GC 3' & B & & \\
\hline \multirow[t]{3}{*}{ PDV } & $5^{\prime}$ CCG GTA TGA TAT CTC GTA CCG AG 3' & $\mathrm{H}$ & 0.61 & (1) \\
\hline & $5^{\prime}$ TAG TGC AGG TTA ACC AAA AGG AT $3^{\prime}$ & $\mathrm{C}$ & & \\
\hline & $5^{\prime}$ GGC GCC ACA GGC GCA TTC AC $3^{\prime}$ & B & & \\
\hline \multirow[t]{3}{*}{ PNRSV } & $5^{\prime}$ AGA CGT CGT GAC AGA CGT CGA AG $3^{\prime}$ & $\mathrm{H}$ & 0.30 & (9) \\
\hline & $5^{\prime}$ TTC TGT ACC TGC CAA TAT CCT ACT TCG 3 & $\mathrm{C}$ & & \\
\hline & $5^{\prime}$ CCG GAC GTC CGA CCA GGA GCC $3^{\prime}$ & B & & \\
\hline \multirow[t]{3}{*}{ ToRSV } & $5^{\prime}$ GGA CGC GTT TGG TCG TTA TGA TTC G $3^{\prime}$ & $\mathrm{H}$ & 0.49 & (19) \\
\hline & $5^{\prime}$ CGA GCC CTG GAA AAA ACG CAA TAA G $3^{\prime}$ & $\mathrm{C}$ & & \\
\hline & $5^{\prime}$ GCC AAC GGA GGT GAT TAG TC $3^{\prime}$ & B & & \\
\hline
\end{tabular}

${ }^{\text {a }}$ CLRV $=$ cherry leafroll virus, $\mathrm{CTV}=$ citrus tristeza virus, $\mathrm{PDV}=$ prune dwarf virus, $\mathrm{PNRSV}=$ prunus necrotic ringspot virus, ToRSV $=$ tomato ringspot virus.

b Oligonucleotide sequence of primers and biotinylated probes used in RT-PCR reaction. The biotinylated probes were modified at their $5^{\prime}$ end. The primers were selected from the coat protein gene for CTV, PDV, and ToRSV; 3' noncoding region for CLRV; and movement protein gene for PNRSV.

${ }^{\mathrm{c}} \mathrm{H}=$ homologous primer, $\mathrm{C}=$ complementary primer, $\mathrm{B}=$ biotinylated probe.

${ }^{\mathrm{d}}$ Expected sizes in kilobases $(\mathrm{kb})$ of PCR products. nator and photographed using Polaroid 667 film.

Colorimetric detection of PCR products. Analysis of PCR products was carried out according to a modification of the protocol found in the Boehringer Mannheim PCR ELISA kit. Microtiter plates were coated with streptavidin $(10 \mathrm{ng} / \mu \mathrm{l}$, $200 \mu \mathrm{l}$ per well) in carbonate buffer (50 $\mathrm{mM}$ sodium carbonate, $\mathrm{pH}$ 9.6) overnight at $4^{\circ} \mathrm{C}$. The plates were then washed three times in ELISA washing buffer and incubated with Blocking buffer (PBS with $1 \%$ Tween 20) for $30 \mathrm{~min}$ at room temperature and washed once more with ELISA washing buffer. Plates were then incubated with virus-specific 5'-biotin-labeled oligonucleotide detection probe $(7 \mathrm{pmol} / \mu \mathrm{l}, 200 \mu \mathrm{l}$ per well, Table 1) for $30 \mathrm{~min}$ at $37^{\circ} \mathrm{C}$ in hybridization buffer (5× SSPE [25], $0.5 \mathrm{M}$ $\mathrm{NaCl}, 0.1 \% n$-lauroylsarcosine, $\mathrm{pH}$ 6.5), and washed three times with ELISA washing buffer. Meanwhile, $20 \mu \mathrm{l}$ of the PCR product was denatured by adding 40 $\mu l$ of denaturing buffer $(0.2 \mathrm{~N} \mathrm{NaOH}, 1.5$ $\mathrm{M} \mathrm{NaCl}$ ), briefly vortexing, and incubating at room temperature for $10 \mathrm{~min}$. The denatured PCR products were neutralized by addition of hybridization buffer to a final volume of $500 \mu \mathrm{l}$.

When the microtiter plates were ready, $200 \mu \mathrm{l}$ of the denatured PCR products were added to duplicate wells and incubated for

Table 2. Comparison between colorimetric (plate) and electrophoretic (gel) analysis of immunocapture polymerase chain reaction (ICPCR) of purified virions (virion), sap extracts from an herbaceous host (cucumber), or sap extracts of woody plants (tree)

\begin{tabular}{lcc}
\hline & \multicolumn{2}{c}{ Detection threshold ${ }^{\mathbf{b}}$} \\
\cline { 2 - 3 } Virus $^{\mathbf{a}}$ & Plate & Gel \\
\hline CLRV & & \\
Virion & $1 \mathrm{fg}$ & $10 \mathrm{pg}$ \\
Cucumber & $10^{-12}$ & $10^{-12}$ \\
Tree & $10^{-6}$ & $10^{-5}$ \\
CTV $^{\mathbf{c}}$ & & \\
Virion & $10^{-6}$ & $10^{-2}$ \\
PDV & & \\
Virion & $100 \mathrm{pg}$ & $1 \mathrm{ng}$ \\
Cucumber & $10^{-17}$ & $10^{-17}$ \\
Tree & $10^{-8}$ & $10^{-8}$ \\
PNRSV & & \\
Virion & $100 \mathrm{fg}$ & $100 \mathrm{pg}$ \\
Cucumber & $10^{-13}$ & $10^{-11}$ \\
Tree & $10^{-5}$ & $10^{-3}$ \\
ToRSV & & \\
Virion & $100 \mathrm{ag}$ & $10 \mathrm{fg}$ \\
Cucumber & $10^{-20}$ & $10^{-19}$ \\
Tree & $10^{-8}$ & $10^{-7}$ \\
\hline CLRV & 16
\end{tabular}

${ }^{\mathrm{a}} \mathrm{CLRV}=$ cherry leafroll virus, $\mathrm{CTV}=$ citrus tristeza virus, $\mathrm{PDV}=$ prune dwarf virus, PNRSV = prunus necrotic ringspot virus, ToRSV $=$ tomato ringspot virus .

b Defined by determining the maximum dilution of plant sap or minimum concentration of pure virions that resulted in detection by each method.

${ }^{c}$ Partially purified virus preparation. Experiments were repeated four to six times, and the calculated average of these results is reported here. 
$1.5 \mathrm{~h}$ at $46^{\circ} \mathrm{C}$. The plates were then washed three times with ELISA washing buffer and incubated for $30 \mathrm{~min}$ at $37^{\circ} \mathrm{C}$ with 200 $\mu \mathrm{l}$ per well of $0.75 \mathrm{U} / \mu \mathrm{l}$ anti-digoxygenin $\mathrm{f}\left(\mathrm{ab}^{\prime}\right) 2$ fragments conjugated to alkaline phosphatase (Boehringer-Mannheim) in loading buffer (1× PBS containing $0.05 \%$ Tween 20, $2.0 \%$ PVP-40, $0.2 \%$ bovine serum albumin, fraction $\mathrm{V}$ ). The plate was then washed once again and incubated at room temperature with colorimetric substrate $(0.75 \mathrm{mg} / \mathrm{ml} p$-nitrophenyl phosphate

Table 3. Comparison of electrophoresis detection versus colorimetric detection of reverse transcription-polymerase chain reaction (RT-PCR) products of sap extracts taken from sweet orange trees infected with five strains of citrus tristeza virus (CTV) and diluted with sap extract from a healthy orange tree

\begin{tabular}{lccccc}
\hline & \multicolumn{2}{c}{ Gel endpoint $^{\mathbf{b}}$} & & \multicolumn{2}{c}{ Plate endpoint $^{\mathbf{b}}$} \\
\cline { 2 - 3 } \cline { 5 - 6 } Strain $^{\mathbf{a}}$ & Exp. 1 & Exp. 2 & & Exp. 1 & Exp. 2 \\
\hline 59B & $10^{-4 \mathrm{c}}$ & $10^{-5}$ & & $10^{-5}$ & $10^{-6}$ \\
65B & $10^{-5}$ & $10^{-3}$ & & $10^{-5}$ & $10^{-4}$ \\
H107B & $10^{-4}$ & $10^{-3}$ & & $10^{-6}$ & $10^{-6}$ \\
H122B & $10^{-4}$ & $10^{-3}$ & & $10^{-6}$ & $10^{-7}$ \\
190B & $10^{-4}$ & $10^{-5}$ & & $10^{-7}$ & $10^{-7}$ \\
\hline
\end{tabular}

${ }^{\mathrm{a}}$ The CTV strains used in this experiment ranged from mild to severe as follows: 59B, severe strain; 65B, mild strain; H107B, severe strain; H122B, severe strain; and 190B, new isolate with host range not known.

${ }^{b}$ In all cases, gel and colorimetric analysis of immunocapture (IC)-PCR of healthy tissue yielded negative results.

${ }^{\mathrm{c}}$ The values reported here represent the maximum dilution that can be achieved without compromising detection. Dilution factors from two independent experiments were compared between electrophoretic (gel) and colorimetric (plate) analysis of IC-PCR products.

\section{A}

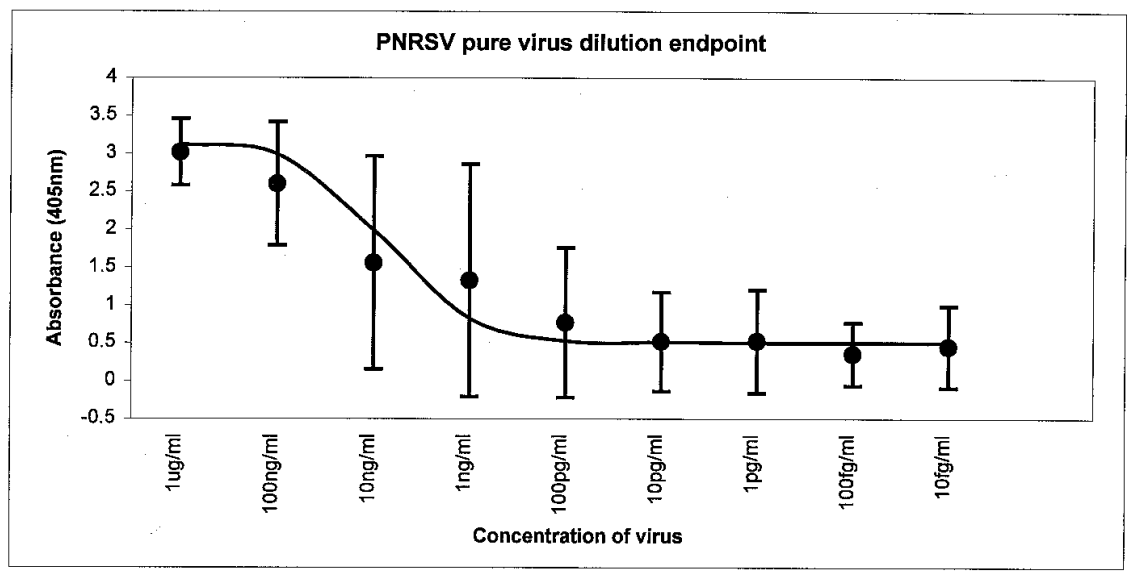

B

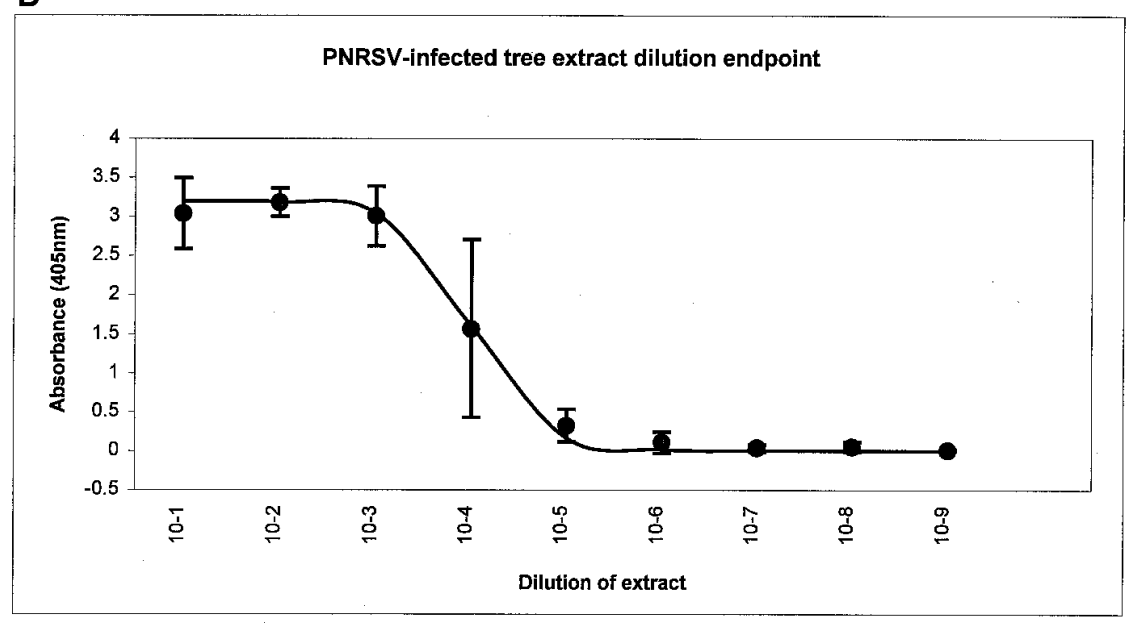

Fig. 1. Dilution endpoint analysis of purified prunus necrotic ringspot virus (PNRSV) and of extracts from PNRSV-infected cherry trees using colorimetric polymerase chain reaction (PCR). (A) Purified PNRSV preparation, (B) extract from PNRSV-infected cherry diluted in extraction buffer.

in $9.5 \%$ diethanolamine, $\mathrm{pH} 9.8$ ) for 1 to 2 h. Color development was then analyzed by measuring absorbance at $405 \mathrm{~nm}$ with a microtiter plate reader (Emax, Molecular Devices, Menlo Park, CA).

Detection thresholds. For each experiment reported in Tables 2 and 3, several dilutions of plant sap or purified virus were analyzed by colorimetric PCR. For each assay, the maximum dilution or minimum amount of pure virion that gave a positive result was recorded. All the data in Tables 2 and 3 are the average of four to six different experiments. Absorbance readings of at least 0.2 were considered positive results, readings below 0.05 were considered negative. Data shown in Figure 1 are the average of four different experiments.

\section{RESULTS}

Electrophoretic analysis of IC-PCR reactions performed on crude sap extracts. Figure 2 shows electrophoretic analysis of IC-PCR products from CLRVW, PDV, PNRSV, and ToRSV, from both healthy and infected cucumber plants, and CTV from healthy and infected orange. In each case, IC-PCR successfully amplified cDNA of the expected size from the infected plants, but not from the healthy control. The specific ToRSV PCR product (460 bp) is accompanied by two smaller, infection-specific products. A nonspecific product is also generated in cucumber by these diagnostic primers. These results were consistent with previous work (21) and are representative of those seen in gel analysis of IC-PCR reactions performed for the comparisons between colorimetric detection and gel electrophoresis.

Colorimetric analysis of IC-PCR reactions. Dilution profiles of virus detection with colorimetric PCR follow the same curves as would be seen with quantitative analysis of PCR products (Fig. 1).

Comparison of colorimetric and electrophoretic analysis of products of ICPCR. A representative set of colorimetric analyses was compared to a parallel set of electrophoretic data for five virusesCLRV-W, CTV, PDV, PNRSV, and ToRSV. For CLRV-W, PDV, PNRSV, and ToRSV, minimum detection limits, using quantitated pure virions, were determined (Table 2). For CTV, minimum detection limit was determined from a partially purified virus preparation. In all cases, neither method gave a positive result with healthy control tissue. Colorimetric PCR was 3, 1, 2, 2, and 4 orders of magnitude more sensitive for PNRSV, PDV, CLRV-W, ToRSV, and CTV, respectively, compared with gel electrophoresis.

To determine the relative effectiveness of these two PCR detection techniques under more realistic conditions, IC-PCR was performed on diluted sap extracts taken from healthy cucumbers or cucumbers infected with CLRV-W, PDV, PNRSV, or ToRSV. Detection thresholds were ap- 
proximately equal for both methods for detection of CLRV-W and PDV, and were 2 and 1 order of magnitude more sensitive (Table 2). Finally, this same experiment was performed using crude extracts taken from healthy and infected trees. Detection thresholds were approximately equal for both methods for detection of PDV, and were 2,1 , and 1 order of magnitude more sensitive for PNRSV, CLRV-W, and ToRSV, respectively.

Comparison of colorimetric and electrophoretic analyses of pooled CTV samples. To test the relative effectiveness of colorimetric PCR on pooled samples, crude sap extracts taken from orange trees infected with five different strains of CTV were serially diluted with sap from healthy orange trees. The results are shown in Table 3. In all cases, colorimetric analysis of IC-PCR products was at least as sensitive as gel analysis of these products.

\section{DISCUSSION}

Several features of colorimetric PCR render it a very useful assay, including increased simplicity, sensitivity, and flexibility. An additional advantage is decreased background relative to gel analysis of ICPCR products. Colorimetric PCR has the potential to be quantitative. Lastly, it for PNRSV and ToRSV, respectively

should be fairly simple for laboratories to adopt this technique.

The majority of the steps required for colorimetric detection of IC-PCR products take place while samples are contained in a 96-well microtiter plate, and gel electrophoresis or blot hybridization steps are eliminated, reducing the number of times individual samples must be handled. This simplicity facilitates the simultaneous processing of large numbers of samples and should make this technique amenable to automation.

IC-PCR detection of woody plant viruses has been reported to be at least four to six orders of magnitude more sensitive than ELISA (21). This sensitivity has two valuable applications for virus detection. First, large numbers of samples can be pooled without compromising the reliability of this assay. This was demonstrated with CTV in Table 3. Second, current detection strategies lack the sensitivity for year-round detection of viruses such as CTV, which have seasonally variable titers (14). In several cases, colorimetric detection was shown to enhance the sensitivity of IC-PCR by up to three orders of magnitude for pure viruses or four orders of magnitude for plant sap extracts. A simple, sensitive, rapid PCR-based analysis would be invaluable to those who need to test for these viruses throughout the year. Further

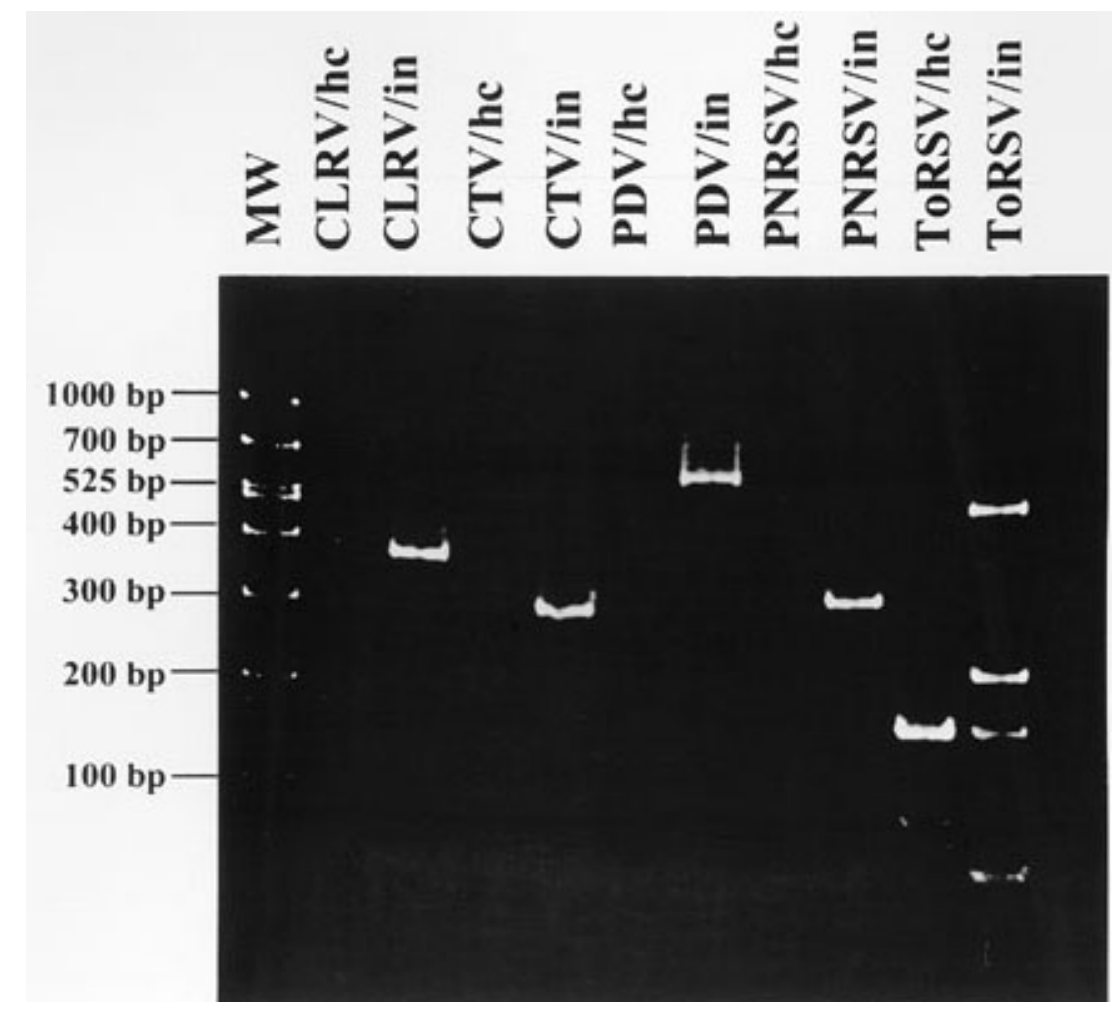

Fig. 2. Gel analysis of immunocapture polymerase chain reaction (IC-PCR) products. IC-PCR was performed using primers to detect cherry leafroll virus (CLRV), prune dwarf virus (PDV), prunus necrotic ringspot virus (PNRSV), and tomato ringspot virus (ToRSV) in extracts from healthy (hc) and infected (in) cucumber (Cucumis sativus), and citrus tristeza virus (CTV) from healthy and infected sweet orange (Citrus sinensis). PCR products were resolved in an $8.5 \%$ polyacrylamide gel (25) and stained with ethidium bromide. Biomarker low range molecular weight markers were used as size standards (MW). The sizes of these standards are depicted to the left of the gel. experimentation with colorimetric PCR is likely to enable it to work routinely at the much higher sensitivities that were achieved in some in the experiments presented here.

PCR primers, required for this assay, can be designed to specifically detect a particular pathogen, or a specific strain of that pathogen. This can be extremely useful to plant pathologists attempting to trace down the origins of an outbreak of a particular virus. Conversely, more general primers can be designed for general detection of a virus or class of viruses by targeting conserved regions. This makes colorimetric PCR amenable to general virus screening efforts such as those run by clean stock programs.

Colorimetric PCR provides a relatively simple means to reduce background problems that can arise during electrophoretic analysis of PCR products. It is not uncommon for RT-PCR primers to hybridize nonspecifically to unintended targets, resulting in spurious PCR products. This can complicate the task of interpreting the data. Assays that employ nucleotide hybridization, such as colorimetric PCR, only detect target-specific PCR products and disregard amplification products arising from nonspecific primer binding.

Colorimetric PCR uses microtiter plates and ELISA plate reading equipment, conferring two additional advantages. First, as the PCR and hybridization steps become more standardized, it will be relatively simple to perform quantitative analyses of viral infection rates within plants. Second, many virus detection facilities already use microtiter plates and plate reading equipment. As a result, it should be fairly easy for facilities to convert to this new assay. Existing equipment can be re-used, and technicians will already know some of the techniques used in colorimetric PCR.

Applications of this technique should be especially useful to clean-stock programs and regulatory agencies worldwide. With the ability to run large numbers of samples, from diverse tissue types and in all seasons, it should be possible to improve the reliability of current pathogen testing protocols. Ultimately, this could lead to significant improvements in the quality of certified nursery stock, streamlining of importation and quarantine programs, and facilitating international trade in plant materials.

\section{ACKNOWLEDGMENTS}

This work was supported by the California Fruit Tree, Nut Tree, and Grapevine Improvement Advisory Board, Citrus Research Board, and Genetic Resources Conservation Program at UC Davis.

\section{LITERATURE CITED}

1. Bachman, E. J., Scott, S. W., Xin, G., and Vance V. B. 1994. The complete nucleotide sequence of prune dwarf ilarvirus RNA 3; implications for coat protein activation of genome replication in ilarviruses. Virology 
201:127-131.

2. Bar-Joseph, M., Gumpf, D. J., Dodds, J. A., Rosner, A., and Ginzberg, I. 1985. A simple purification method for citrus tristeza virus and estimation of its genome size. Phytopathology 75:195-198.

3. Borja, M. J., and Ponz, F. 1992. An appraisal of different methods for the detection of the walnut strain of cherry leafroll virus. J. Virol. Methods 36:73-83.

4. Crosslin, J. M., and Mink, G. I. 1992. Biological differences among prunus necrotic ringspot ilarviruses. Phytopathology 82:200206.

5. Fulton, R. W. 1957. Properties of certain mechanically transmitted viruses on prunus. Phytopathology 47:683-687.

6. Fulton, R. W. 1959. Purification of sour cherry necrotic ringspot and prune dwarf viruses. Virology 9:522-535.

7. Golino, D. A., Verdegaal, P., Rowhani, A., and Walker, M. A. 1992. Sampling procedures to find nepoviruses in grapevines need improvement. Calif. Agric. 46:11-13.

8. Graff, J., Ticehurst, J., and Fleming, B. 1993. Detection of hepatitis-A antigen in sewage sludge by antigen capture polymerase chain reaction. Appl. Environ. Microbiol. 59:31653170.

9. Hammond, R. W., and Crosslin, J. M. 1995. The complete nucleotide sequence of RNA 3 of a peach isolate of prunus necrotic ringspot virus. Virology 208:349-353.

10. Hoy, J. W., and Mircetich, S. M. 1984. Prune brownline disease: Susceptibility of prune rootstocks and tomato ringspot virus detection. Phytopathology 74:272-276.

11. Jansen, R. W., Siegl, G., and Lemon, S. M.
1990. Molecular epidemiology of human hepatitis virus-A defined by antigen-capture polymerase chain reaction. Proc. Natl. Acad. Sci. USA 87:2867-2871.

12. Kawasaki, E. S. 1990. Amplification of RNA. Pages 21-27 in: PCR Protocols, a guide to methods and applications. M. A. Innis, D. H. Gelfand, J. J. Sninsky, and T. J. White, eds. Academic Press, New York.

13. Lion, T., and Haas, D. A. 1990 . Nonradioactive labeling of probe with digoxygenin by polymerase chain reaction. Anal. Biochem. 88:335-337.

14. Mathews, D. M., Riley, K., and Dodds, J. A. 1997. Comparison of detection methods for citrus tristeza virus in field trees during months of nonoptimal titer. Plant Dis. 81:525529.

15. Mawassi, M., Gafny, R., and Bar-Joseph, M. 1993. Nucleotide sequence of the coat protein gene of citrus tristeza virus: Comparison of biologically diverse isolates collected in Israel. Virus Genes 7:265-275.

16. Mircetich, S. M., and Rowhani, A. 1984. The relationship of cherry leafroll virus and blackline disease of English walnut trees. Phytopathology 74:423-428.

17. Nolasco, G., deBlas, C., Torres, V., and Ponz, F. 1993. A method combining immunocapture and PCR amplification in a microtiter plate for the detection of plant viruses and subviral pathogens. J. Virol. Methods 45:201-218.

18. Prevot, J., Dubrou, S., and Marechal, J. 1993. Detection of human hepatitis-A virus in environmental water by antigen-capture polymerase chain reaction method. Water Sci. Technol. 27:227-233.

19. Rott, M. E., Tremaine, J. H., and Rochon, D.
M. 1991. Nucleotide sequence of tomato ringspot virus RNA-2. J. Gen. Virol. 72:1505 1914.

20. Rowhani, A., Chay, C., Golino, D. A., and Falk, B. W. 1993. Development of a polymerase chain reaction technique for the detection of grapevine fanleaf virus in grapevine tissue. Phytopathology 83:749-753.

21. Rowhani, A., Maningas, M. A., Lile, L. S., Daubert, S. D., and Golino, D. A. 1995. Development of a detection system for viruses of woody plants based on PCR analysis of immobilized virions. Phytopathology 85:347 352.

22. Rowhani, A., Mircetich, S. M., Shepherd, R. J., and Cucuzza, J. D. 1985. Serological detection of cherry leafroll virus in English walnut trees. Phytopathology 75:48-52.

23. Rowhani, A., Walker, M. A., and Rokni, S. 1992. Sampling strategies for the detection of grapevine fanleaf virus and the grapevine strain of tomato ringspot virus. Vitis 32:3544.

24. Saiki, R. K., Scharf, S., Faloona, F., Mullis, K., Horn, G. T., Elrich, H. A., and Arnheim, N. 1985. Enzymatic amplification of $\gamma$-globin genomic sequences and restriction site analysis for diagnosis of sickle cell anemia. Science 230: 1350-1354.

25. Sambrook, J., Fritsch, E. F., and Maniatis, T. 1989. Molecular Cloning: A Laboratory Manual. 2nd. ed. Cold Spring Harbor Press, Cold Spring harbor, NY.

26. Wetzel, T., Candresse, T., Macquaire, G., Raveloandro, M., and Dunez, J. 1992. A highly sensitive immunocapture polymerase chain reaction method for plum pox potyvirus detection. J. Virol. Methods 39:27-37. 